\title{
Penempatan Photovoltaic yang Optimal Menggunakan Metode Continuation Power Flow
}

\author{
Sitti Marwah Rachman ${ }^{1 *}$, Muhammad Bachtiar Nappu ${ }^{1,2}$, Ardiaty Arief ${ }^{1,2}$. \\ ${ }^{1}$ Departmen Teknik, Fakultas Teknik Elektro, Universitas Hasanuddin, \\ Jl. Poros Malino, Borongloe-Bontomarnnu, Gowa 92171, Sul-Sel, Indonesia \\ ${ }^{2}$ Lembaga Penelitian dan Pengabdian kepada Masyarakat (LP2M), Universitas Hasanuddin, \\ J1. Perintis Kemerdekaan Km. 10, Tamalanrea, Makassar 90245, Sul-Sel, Indonesia \\ *E-mail: marwah_rachman@yahoo.com
}

DOI: 10.25042/jpe.052017.10

\begin{abstract}
Abstrak
Makalah ini menyajikan sebuah metode aliran daya untuk memperkirakan lokasi penempatan pembangkit Photovoltaic (PV) yang optimal pada sistem distribusi. Metode ini sebagai metode untuk mengindentifikasi bus sistem yang paling sensitif. Pada Analisis dan simulasi ini dilakukan pada 44 bus, 47 line, dan 7 generator. Adapun efek penempatan PV yang tepat dengan metode Continuation Power Flow (CPF) adalah dapat meningkatkan profil tegangan dan dapat mengatasi ketidakstabilan tegangan, sehingga analisis dan evaluasi kestabilan tegangan dapat terlihat pada kondisi sebelum dan sesudah penambahan PV. Penelitian ini mengidentifikasi daerah-daerah yang memiliki radiasi matahari yang baik dari SOLARGIS data. Daerah yang memiliki irradiance yang baik menjadi input PV. Dari hasil analisa power flow menemukan daerah yang memiliki irradiance yang baik dan sensitivitas yang baik, dan bisa direkomendasikan untuk penempatan PV untuk membantu pelayanan beban yang semakin meningkat tiap tahunnya.
\end{abstract}

\begin{abstract}
Optimal Photovoltaic Placement using Continuation Power Flow Method. This paper presents a method of power flow for estimating the optimal placement of Photovoltaic (PV) plants in the distribution system. This method as a method to identify the most sensitive bus system. In the analysis and simulation is done on 44 buses, 47 lines, and 7 generators. The right PV placement effect with the Continuation Power Flow (CPF) method is able to increase the voltage profile and can overcome voltage instability, so that the analysis and evaluation of voltage stability can be seen on the condition before and after the addition of PV. This study identifies areas that have good solar radiation from SOLARGIS data. The area that has a good irradiance becomes a PV input. Power flow analysis finds areas that have good irradiance and good sensitivity, and can be recommended for PV placement to help the burden service increase each years.
\end{abstract}

Kata-kunci: Continuation Power Flow, Photovoltaic, Sensitivitas, Stabilitas Tegangan

\section{Pendahuluan}

Kestabilan tegangan yang berkaitan dengan kemampuan sistem tenaga listrik untuk mempertahankan tegangan di setiap bus pada kondisi abnormal maupun karena adanya gangguan [1, 2]. Sumber energi terbarukan sebagai alternative untuk generator bahan bakar konvensional menjadi perhatian oleh seluruh dunia. Sistem akan memasuki keadaan ketidakstabilan tegangan ketika terjadi gangguan, peningkatan permintaan beban dan adanya perubahan kondisi sistem. Keadaan tersebut akan menyebabkan penurunan performa sistem, sehingga tegangan menjadi tidak terkendali, akibatnya profil tegangan menurun dan kerugian daya (Losses) pada sistem distribusi semakin besar, akibat fatal dari kondisi tersebut adalah terjadinya pemadaman atau blackout pada daerah sekitar [3, 4].

Penempatan PV pada lokasi yang tepat dalam system transmisi akan menjaga utilitas tegangan, namun jika penempatan PV pada lokasi yang tidak tepat akan menyebabkan system stabilitas terpengaruh. Dan apabila PV terhubung pada lokasi yang strategis akan menyebabkan system lebih stabil [5].

Sejak Unit PV dapat diinstal dekat dengan pusat beban, maka dapat memperbaiki profil tegangan, meminimalkan rugi-rugi daya, dan 
pencapaian penurunan gas emisi gas rumah kaca [6-9].

Karena penurunan signifikan terhadap bahan bakar fosil dan kekwatiran terhadap dampak hijau, maka saat ini seluruh dunia beralih ke sumber energi terbarukan seperti energi matahari, angin, laut, hydro, dan panas bumi [10-12]. Diantara sumber energi terbarukan yang ada, sumber energi matahari banyak dilirik oleh para insyinyur karena kinerjanya tidak mencemari lingkungan dalam menghasilkan listrik dan mampu memanen energi dari matahari, yang merupakan sumber energi bebas setelah fasilitas tersebut terpasang [13, 14]. Sejak tahun 1970an negara Indonesia telah menerapkan sistem PV sebagai sumber tenaga listrik untuk di pulau-pulau kecil, namun pada tahun 1997 sempat berhenti karena terjadi krisis keuangan saat itu [15].

Radiasi cahaya matahari yang sampai dipermukaan atmosfer bumi tidak semuanya diterima oleh permukaan bumi karena mengalami proses pengamburan oleh awan atau juga partikelpartikel lain yang ada dalam atmosfer. Untuk menstabilkan $\mathrm{CO} 2$ diatmosfer pada pertengahan abad ini, PV digunakan untuk listrik $10 \mathrm{TW}$, hydrogen untuk transportasi $10 \mathrm{TW}$, dan bahan bakar fosil untuk perumahan dan industri $10 \mathrm{MW}$ [16]. Hal demikian, PV memegang peranan sangat penting dalam memenuhi permintaan energi dunia.

Partikel CO2 sifatnya selalu menghindari emisi dari teknologi PV selama beroperasi. Pada pembagian kelompok negara, $\mathrm{CO} 2$ dalam menghindari emisi PV sekitar 35 dan 40 ton. Untuk kelompok pertama negara, yakni Turkmenistan, Irak,Eritrea, Kuwait, arab Saudi, Oman, afrika Selatan, Australia, Kuba, India dan Cina barat. Kelompok ini merupakan negara yang mempunyai potensi paling tinggi dalam pengurangan CO2. Sedangkan Negara Maroko, Kamboja, Israel, Indonesia, Jamaika, Yaman, Uni Emirat Arab, Amerika Serikat Barat, Cina Timur dan Republik Dominika masuk dalam kelompok kedua dalam pengurangan sebesar 25 dan 30 ton $\mathrm{CO} 2$ per $\mathrm{kWp}$ selamanya. Sistem PV secara inheren dapat menghindari emisi $\mathrm{CO} 2$ saat $\mathrm{PV}$ beroperasi karena dapat menggantikan bagian dari sumber fosil. Penulis L. S-Luj_an, N. Espinosa, J. Abad, dan A. Urbina menejelaskan bahwa negara
Ethiopia, Mozambil, Zambia dan Islandia ditemukan sebagai tempat terbaik untuk pembuatan PV, sedangkan negara Botswana, Turkmenistan, Kosovo, Afrika selatan dan Australia merupakan lokasi terbaik untuk penempatan PV [17].

Pada makalah ini penulis hanya melakukan analisis tentang penempatan PV yang optimal pada daerah yang memiliki radiasi yang baik sesuai data SOLARGIS dan sensitivitas yang baik setelah dianalisis pada metode CPF. Penempatan PV pada lokasi yang tepat pada sistem transmisi sangat penting untuk menjaga stabilitas tegangan. Pada pemasangan generator PV di jaringan distribusi menunjukkan perbaikan profil tegangan dan pengurangan rugi-rugi daya. Karena daerah Sulawesi Selatan khususnya Makassar merupakan salah satu daerah yang memiliki radiasi yang baik, sehingga menjadi objek integrase PV di Indonesia. Bus dengan radiasi dengan sensitivitas yang baik direkomendasikan untuk penempatan PV optimal.

Struktur makalah ini yaitu bagian ke 2 menjelaskan tentang teori dasar photovoltaic, Irradiance, Kestabilan tegangan. Bagian 3 metode yang digunakan. Bagian 4 hasil dan analisis yang di sajikan. Bagian 5 adalah menyimpulkan temuan utama dari hasil penelitian ini.

\section{Teori Dasar}

\subsection{Photovoltaic}

Photovoltaic adalah suatu alat yang dapat mengkonversi cahaya matahari menjadi listrik secara langsung. Kata photovoltaic biasa disingkat dengan PV. Material utama yang digunakan dalam pembuatan PV adalah silikon[18]. Photovoltaic dapat bekerja secara optimum dalam kondisi tertentu dan ramah terhadap lingkungan [19]. Pengoperasian maksimum sel surya sangat tergantung pada temperatur panel surya, radiasi solar, keadaan atmosfir bumi, orientasi panel surya atau array PV, serta letak panel surya (array) terhadap matahari (tilt angle).

Bahan semikonduktor seperti silicon, gallium arsenide, dan cadmium telluride atau copper indium deselenide biasanya digunakan sebagai bahan bakunya. Solar cell crystalline biasanya digunakan secara luas untuk pembuatan solar cell. 
Solar cell atau panel surya adalah alat untuk mengkonversi tenaga matahari menjadi energi listrik. PV dikemas dalam sebuah unit yag disebut modul. Dalam sebuah modul surya terdiri dari banyak sel surya yang bias disusun secara seri dan parallel. Sedangkan yang dimaksud dengan surya adalah sebuah elemen semikonduktor yang dapat mengkonversi energi surya menjadi energi listrik atas dasar efek PV. Pada Gambar 1 memperlihatkan cara kerja sistem pembangkit listrik tenaga surya, menggunakan grid-connected panel sel surya photovoltaic; modul sel surya PV mengubah energi surya menjadi arus listrik DC, arus listrik DC yang dihasilkan akan dialirkan melalui inverter (konversi daya) yang mengubahnya menjadi arus listrik AC, yang secara otomatis juga akan mengatur seluruh sistem. Listrik AC akan didistribusikan melalui panel distribusi indoor yang akan mengalirkan listrik sesuai kebutuhan alat elektronik (televisi, radio, AC, pompa air dll). Besar dan biaya konsumsi listrik yang dipakai akan diukur dalam Watt-Hour Meters.

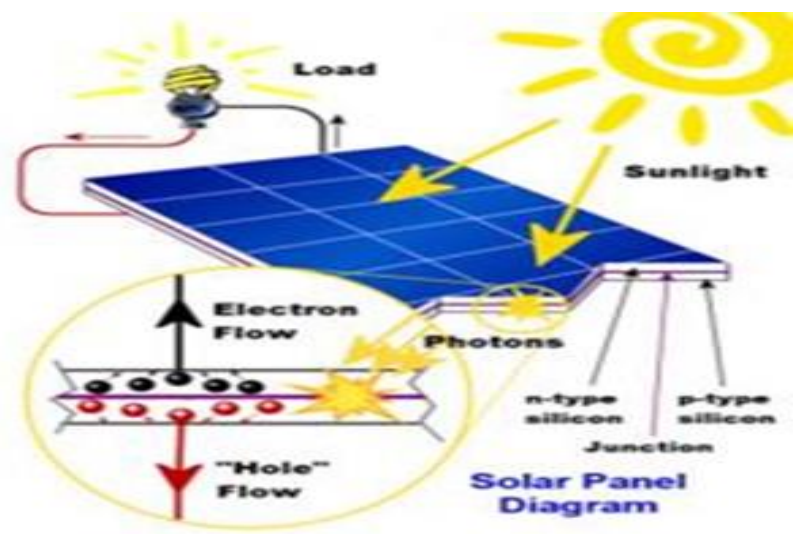

Gambar 1. Cara kerja solar sel

\subsection{Irradiance}

Iradiasi matahari merupakan parameter yang sangat penting untuk sel PV, karena fungsinya seperti bahan bakar pembangkit listrik konvensional yang membuat sistem mampu bekerja. Nilai standar radiasi adalah $1000 \mathrm{~W} / \mathrm{m}^{2}$, semakin banyak iradiasi maka semakin bagus arus yang dihasilkan [20].

Iradiasi matahari yang sampai kepermukaan atmosfer bumi tidak semuanya diterima oleh permukaan bumi karena mengalami proses pengamburan oleh awan atau juga partikelpartikel lain yang ada didalam atmosfer bumi.
Indonesia merupakan Negara yang berada digaris khatulistiwa, sehingga memiliki potensi energi matahari yang cukup tinggi, karena matahari terus ada sepanjang tahun. Wilayah Indonesia bagian barat rata-rata matahari bersinar yang berpotensi menghasilkan energi yaitu $4-5$ jam perhari. Untuk wilayah Indonesia bagian barat meliputi Aceh, Sumatra barat, Sumatra utara, Riau, Kepulauan riau, dan jambi memiliki potensi energi rata-rata $4,5 \mathrm{kWh} / \mathrm{m}^{2} /$ hari, sedangkan wilayah Indonesia bagian timur meliputi seluruh papua, maluku, nusa tenggara timur, nusa tenggara barat, dan sebagian Sulawesi memiliki potensi energi rata-rata $5,1 \mathrm{kWh} / \mathrm{m}^{2} /$ hari. Berdasarkan data dari Dewan Energi Nasional potensi energy matahari diindonesia mencapai rata-rata sekitar $4,8 \mathrm{kWh}$ permeter persegi perhari atau setara dengan $112.000 \mathrm{GWp}$ [21].

Untuk wilayah Sulawesi selatan nilai radiasi bernilai sekitar $1607 \mathrm{kWh} / \mathrm{m}^{2} /$ tahun. Energi matahari yang sampai ke permukaan bumi biasanya dihitung oleh iradiasi horizontal global (GHI). Untuk nilai rata-rata dalam jangka panjang dari Photovoltaic power production potential (PVOUT) ditentukan oleh berbagai faktor termasuk garis lintang, elevasi, bentuk lahan dan banyak variabel meteorologi lainnya [18]. Jumlah PVOUT pada tahun 2017 di indonesia ditunjukkan pada Gambar. 2 yang telah diperkirakan oleh SolarGIS [22].

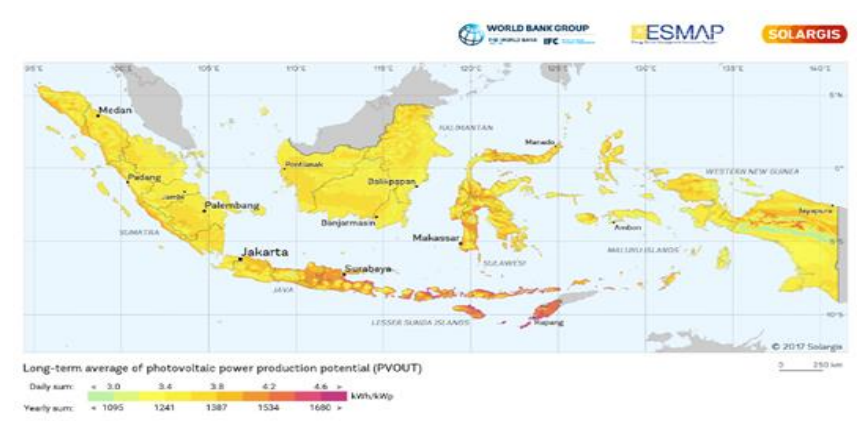

\section{Gambar 2. Long-term average of photovoltaic power production potential.}

\subsection{Kestabilan Tegangan Sistem Tenaga Listrik}

Kestabilan tegangan sangat berhubungan dengan kemampuan sistem tenaga untuk tetap stabil pada semua bus, tidak hanya dibawah kondisi normal operasi, tetapi juga setelah terjadinya gangguan. Kestabilan tegangan merupakan masalah penting dalam sistem daya 
modern saat ini. Kebutuhan daya yang sangat besar memungkinkan terjadinya pendekatan batas titik tegangan jatuh dalam sistem.

Dengan meningkatnya kebutuhan daya pada masyarakat, dapat memiliki efek negatif terhadapat kestabilan tegangan. Jika ada sedikit kenaikan pada kebutuhan beban, maka permintaan daya reaktif akan lebih besar dari suplai, dan tegangan akan menurun. Dengan menurunnya nilai tegangan, perbedaan antara suplai daya reaktif dan permintaan menjadi meningkat, dan saat tegangan terus menurun maka akan menjadi nilai yang sangat kecil, kejadian ini biasa disebut sebagai tegangan jatuh.

Dalam sistem tenaga listrik yang baik maka harus memenuhi 3 syarat yaitu; 1. Reliability adalah kemampuan suatu sistem untuk menyalurkan daya atau energi secara terus menerus. 2. Quality adalah kemampuan sistem tenaga listrik untuk menghasilkan besaranbesaran standar yang ditetapkan untuk tegangan dan frekuensi. 3. Stability adalah kemampuan dari sistem untuk kembali bekerja secara normal setelah mengalami suatu gangguan. Jika semua terpenuhi maka sistem mampu memberi pasokan listrik secara terus menerus dengan standar besaran untuk tegangan dan frekuensi sesuai dengan aturan yang berlaku dan harus segera kembali normal bila sistem terkena gangguan [23].

\section{Metode Penelitian}

\subsection{Continuation Power Flow}

Pada umumnya Continuation Power Flow menggunakan metode newton rapshon untuk menghitung aliran daya dari sebuah sistem tenaga yang digunakan sebagai data awal yang selanjutnya akan diolah untuk membentuk kurva P-V dengan adanya penambahan beban secara terus menerus, namun dalam kondisi penggunaan metode newton raphson pada sistem tertentu matriks Jacobian yang dihasilkan menjadi singular.

Metode CPF adalah salah satu metode untuk menganalisis stabilitas voltase quasi-statis. Tujuan metode CPF adalah untuk mendapatkan solusi aliran daya terhadap beban yang diberikan. Metode CPF yang dijelaskan dalam makalah ini merupakan hasil kajian oleh Ajjarapu dan Christy. Seperti pada Gambar 3 memperlihatkan prosedur analisis dimulai dari hasil yang telah diketahui kemudian dilanjutkan nilai parameter beban yang berbeda[24].

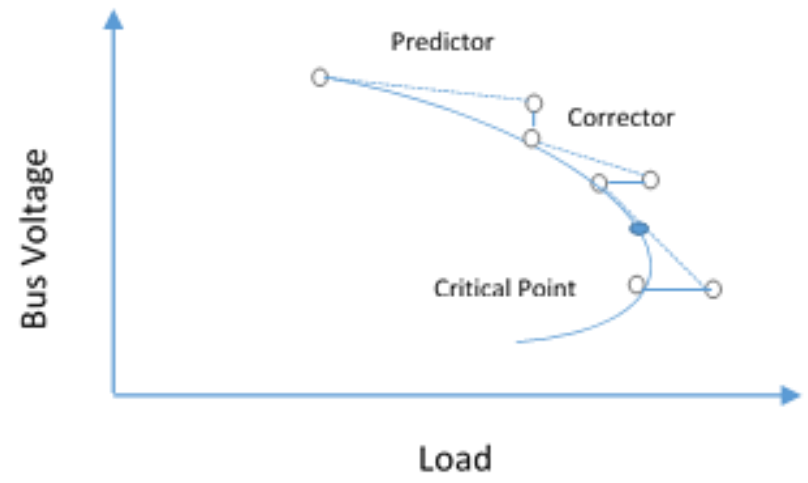

Gambar 3. Skema Predictor-corrector pada CPF

Hal pertama yang dilakukan adalah, dimisalkan $\varphi$ sebagai parameter beban, maka $\delta$ didefinikan sebagai :

$$
0 \leq \phi \leq \phi \text { critical }
$$

Dimana $\varnothing=0$ memiliki hubungan dengan beban dasar dan $\varnothing=\varnothing$ critical dan berhubungan dengan beban kritis. Parameter beban ini kemudian dimasukkan kedalam persamaan daya aktif dan reaktif, sehingga:

$$
\begin{aligned}
& \left.0=P_{G i O}\left(1+\lambda_{k G i}\right)-P_{L i O}-\phi\left(k_{L i} S_{\Delta b a s e}\right) \cos \theta \mathrm{i}\right)-P_{T i} \\
& 0=P_{G i O}-Q_{L i O}-\phi\left(k_{L i} S_{\Delta b a s e} \sin \theta i\right)-Q_{T i}
\end{aligned}
$$

Dimana:

$P_{L i O}, P_{G i O}$ merupakan beban pasti pada bus $i$, active dan reactive load.

$k_{L i}$ merupakan indicator yang menunjukkan tingkat perubahan beban pada bus $i$ terhadap perubahan $\emptyset$

$\theta_{i}$ merupakan sudut daya dari perubahan beban terhadap bus $i$

$S_{\Delta b a s e}$ merupakan kualitas dari daya semu yang dipilih untuk menginjeksikan skala yang tepat dari $\emptyset$

$P_{G i O}$ merupakan daya aktif pada generator terhadap bus i sebagai studi kasus

$k_{G i}$ merupakan nilai konstan pada generator untuk menenetukan tingkat perubahan yang bervariasi pada generator terhadap $\emptyset$ 
$P_{T i}, Q_{T i}$ merupakan parameter daya aktif dan reaktif yang di berikan pada sistem.

Setelah langkah pertama dilakukan maka dilanjutkan dengan komputasi pada algoritma menggunakan persamaan aliran daya sebagai berikut:

$$
F(\delta, V, \phi)=0
$$

dimana adalah $\delta$ vektor sudut generator, $\mathrm{V}$ adalah vektor magnitude tegangan bus dan $\emptyset$ adalah parameter pembebanan.

Metode CPF menjabarkan sebuah skema langkah korektor prediktor untuk mencari solusi persamaan aliran daya yang direformulasi. Di prediksi pada tangen vektor dihitung dengan menurunkan kedua sisi persamaan aliran daya, sehingga:

$$
\left[F_{\delta} F_{V} F_{\phi}\right]\left[\begin{array}{l}
d \delta \\
d V \\
d \phi
\end{array}\right]=0
$$

Selanjutnya,

Dari persamaan lima di lakukan koreksi dengan memperluas parameterisasi yang telah di indentifikasi dari setiap solusi yang telah didapatkan setelah dilakukan proses komputasi. Hasil yang di peroleh akan menunjukkan setiap bus terlemah pada system. Bus yang paling sensitife memiliki rasio besaran perubahan diferensial tegangan terhadap perubahan diferensial perubahan beban. Oleh Karena itu, dalam penelitian ini kami memformasikan PVSensitivity untuk menentukan lokasi PV sebagai berikut :

$$
\begin{aligned}
& P V \text { Sensitivity } j=\left|\frac{d V_{j}}{d P_{\text {total }}}\right|=\left|\frac{d V_{j}}{C d_{\phi}}\right|= \\
& \max || \frac{d V_{1}}{C d_{\phi}}|,| \frac{d V_{2}}{C d_{\phi}}|, \ldots . .| \frac{d V_{n}}{C d_{\phi}}||
\end{aligned}
$$

\subsection{Flowchart of the proposed method}

Gambar 4 memperlihatkan sebuah diagram alir dari PV yang coba diusulkan dengan menggunakan metode CPF dan info iradiance. Setelah dilakukan studi aliran daya dan analisis stabilitas tegangan langkah selanjutnya adalah menjalankan $\mathrm{CPF}$ dan menghitung PV Sensitivitas dalam menentukan ketidakstabilan pada sistem. Hasil yang menunjukkan nilai tegangan yang terlemah kemudian dijadikan prioritas penempatan PV kemudian dilakukan proses komputasi untuk melihat nilai perubahan tegangan yang ada. Jika kendala terpenuhi maka, akan didapatkan lokasi yang optimal dalam pemasangan PV.

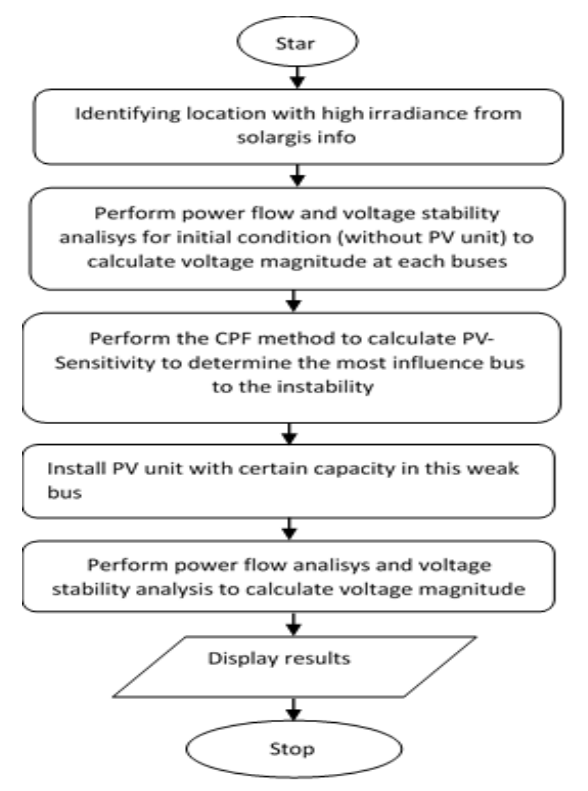

Gambar 4. Flowchart penempatan PV dengan metode CPF [25].

\section{Hasil dan Analisis}

Berdasarkan data solarGis, daerah Sulawesi Selatan khususnya kota makassar yang memiliki irradiance yang baik dan menjadi input pada sistem jaringan yaitu Tallo Lama, Panakukang, dan Daya.

Metode yang diusulkan dilakukan pada sistem interkoneksi sistem tenaga di Sulawesi Selatan terdiri dari 44 Bus, 47 line dan 7 Generator yang dimodelkan untuk dilakukan riset penempatan PV guna mencari titik optimal dari setiap PV berdasarkan data SolarGis. Daya pembangkitan setiap PV yang disimulasikan sebesar $20 \mathrm{MW}$ yang akan di uji pada sistem. Pada Tabel 1 memperlihatkan nama - nama Bus yang memiliki 
irradiance yang tinggi berdasarkan data solarGis. Berdasarkan data solarGis, kota makassar merupakan salah satu daerah yang memiliki irradiance yang baik. Di Makassar sendiri terdapat beberapa gardu induk. Mengingat Makassar merupakan ibukota propinsi dan sangat padat, maka untuk penelitian ini, perhitungan sensitivitas di makassar diwakili oleh 3 substantions : yaitu; Tallo Lama, Panakukang, dan Daya.

Diperoleh data bahwa penempatan PV yang memiliki irradiance yang baik dan sensitivitas yang paling baik adalah terdapat pada Tallo Lama, disusul panakukang, dan selanjutnya adalah daya. Dan pada Tabel 2 memperlihatkan nilai sensitivitas di setiap substation yang memiliki irradiance yang baik setelah dilakukan simulasi pemasangan PV pada sistem.

Tabel 1. Bus yang memiliki irradiance tinggi

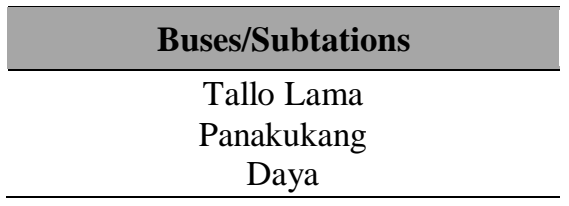

Tabel 2. Nilai Sensitivitas PV

\begin{tabular}{c|c}
\hline Unit & PV-Sensitivity \\
\hline Tallo Lama & 0.94158 \\
Panakukang & 0.79649 \\
Daya & 0.12497 \\
\hline
\end{tabular}

Dari data didapatkan Tallo Lama memiliki sensitivitas yang paling tinggi yaitu sebesar 0.94158, disusul Panakukang sebesar 0,79649.. Sementara unit yang memiliki sensivitas rendah terdapat pada Daya 0,12497. Pada gambar 5 mempelihatkan Gambar schema single line sulbagsel oktober 2016 dari PLN.

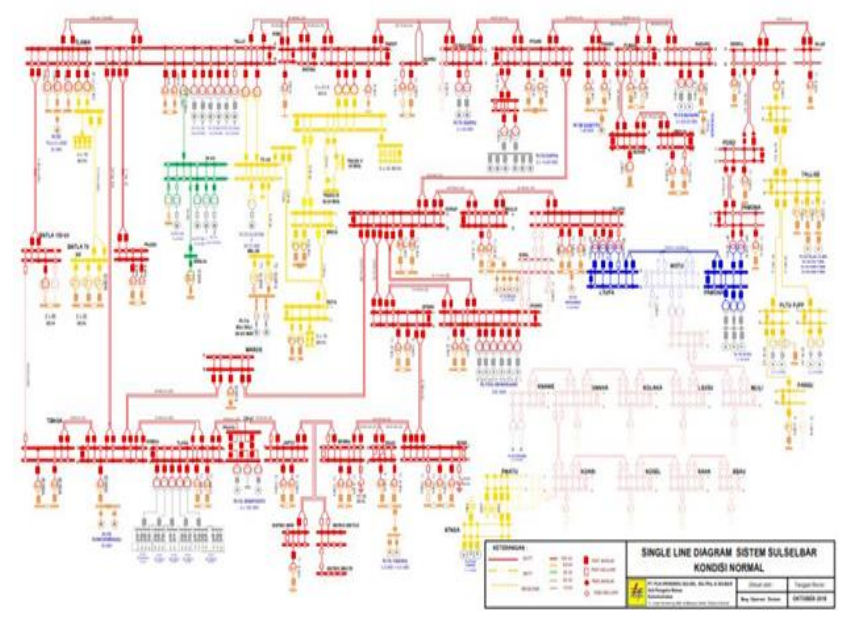

Gambar 5. Single line sulbagsel

Sebelum dilakukan simulasi penempatan PV, maka terlebih dahulu menjalankan power flow dalam keadaan normal. Gambar 6 memperlihatkan skema aliran daya dalam keadaan normal (tanpa PV).

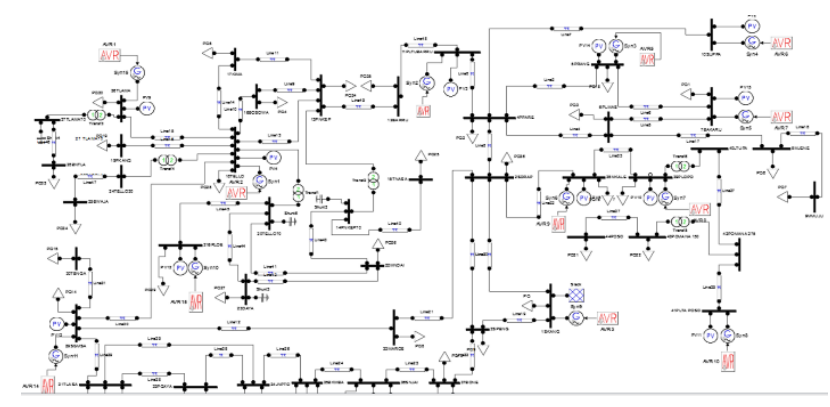

Gambar 6. Skema aliran daya kondisi normal

Saat dilakukan simulasi pemasangan PV dari beberapa buses/substations sesuai data solarGis yang memiliki irradiance baik, maka terlihat hasil pada Gambar 7 voltage magnitude profil Tallo Lama yang memiliki sensitivitas yang baik.

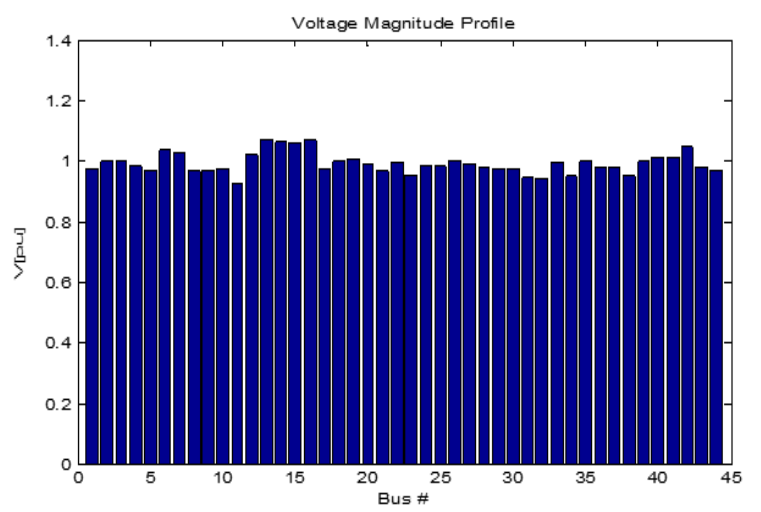

Gambar 7. Grafik magnitude tegangan bus Tallo Lama 


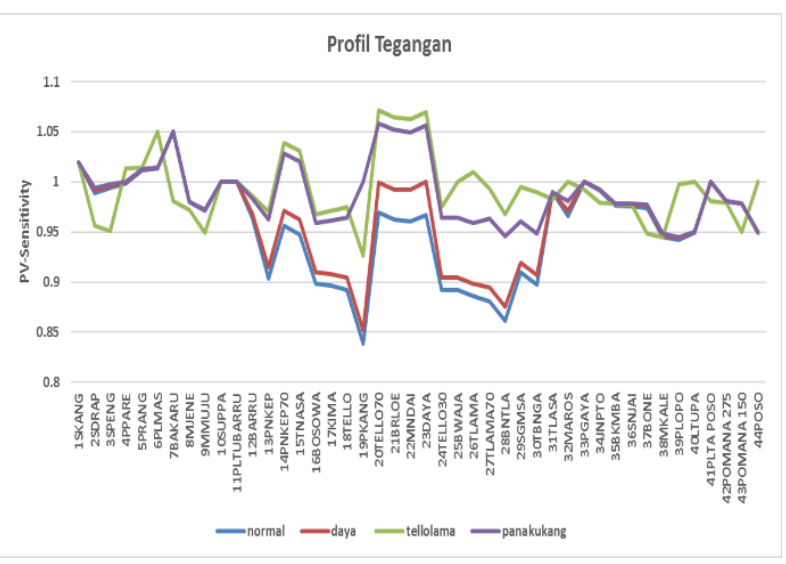

Gambar 8. Profil Tegangan untuk semua skenario

Gambar 8 memperlihatkan profil tegangan untuk semua skenario pemasangan PV. Secara umum, terlihat sistem tegangan untuk simulasi pemasangan PV $20 \mathrm{MW}$ di bus paling baik yang ditunjukkan oleh grafik dengan warna hijau. Untuk lebih jelasnya, Gambar 9 memperlihatkan grafik tegangan untuk kondisi awal dan tegangan pada scenario dengan sensitivitas tertinggi (Tallo Lama) dan sensitivitas rendah (Doso). Dan pada gambar ini terlihat sangat jelas perbandingan substation yang memiliki sensitivitas tinggi dan rendah.

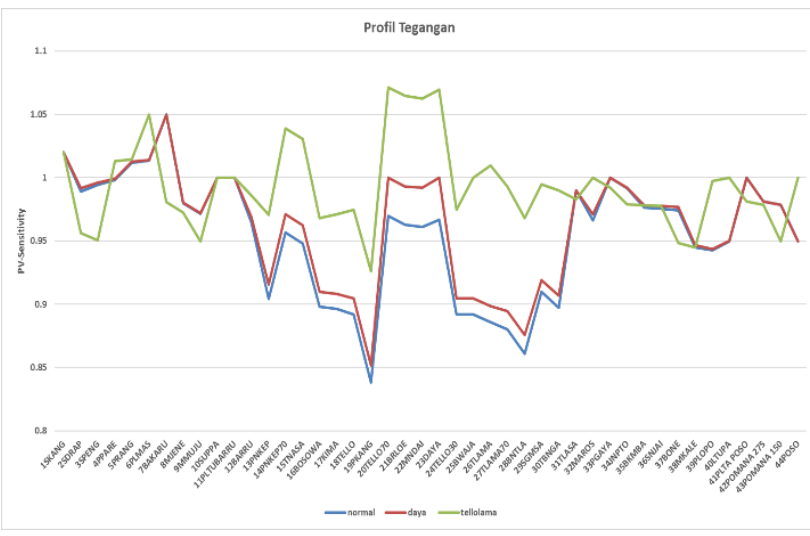

Gambar 9. Profil Tegangan dengan sensitivitas tinggi dan rendah

Setelah dilakukan pemasangan PV pada sistem berdasarkan data SolarGis, didapatkan pula nilai losses jaringan disetiap subtations yang dijadikan untuk penempatan PV pada sistem Sulbagsel. Tabel 3 dan Gambar 9a dan 9b menunjukkan total losses tertinggi berada pada subtation Daya, dimana untuk rugi daya aktif yaitu sebesar 0,44882 p.u dan rugi daya reaktif sebesar 2.20639 p.u. Sementara Tallo Lama dengan PV-Sensitivitas tertinggi memiliki losses terkecil dibanding skenario lainnya, yakni 0.43348 p.u untuk rugi daya aktif dan 2.16255 p.u untuk rugi daya reaktif.

Tabel 3. Rugi-rugi daya setiap scenario

\begin{tabular}{ccc}
\hline PV Location & $\begin{array}{c}\text { REAL POWER } \\
\text { [p.u.] }\end{array}$ & $\begin{array}{c}\text { REACTIVE } \\
\text { POWER [p.u.] }\end{array}$ \\
\hline Tallo Lama & 0.43348 & 2.16255 \\
Panakukang & 0.43774 & 2.16786 \\
Daya & 0.44882 & 2.20639 \\
\hline
\end{tabular}

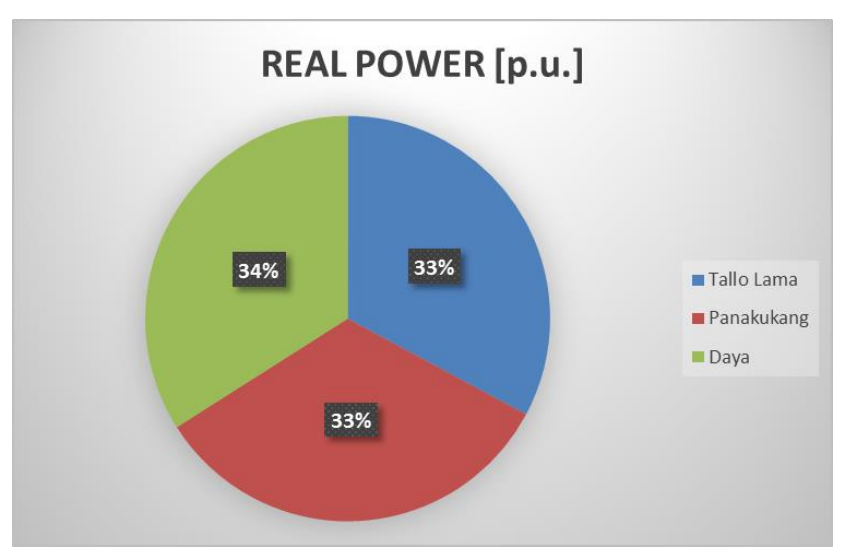

Gambar 9a. Losses Real power

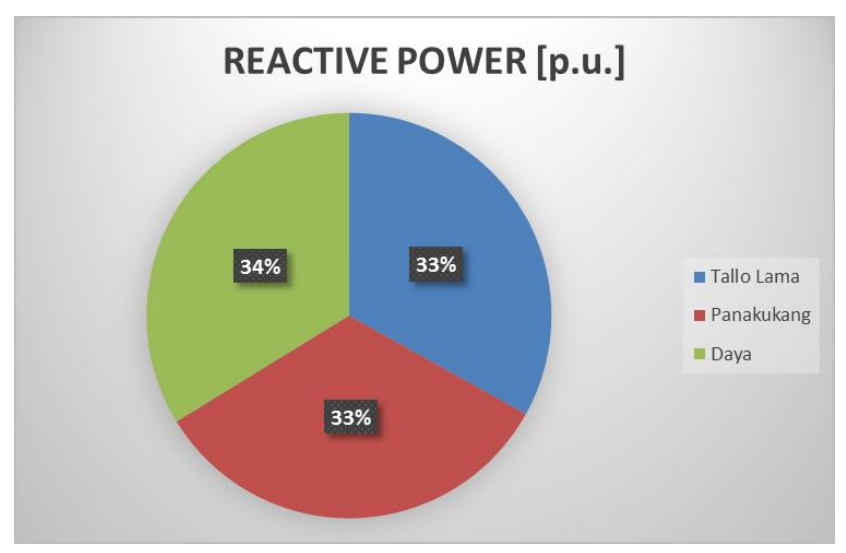

Gambar 9b. Losses Reactive power

Tabel 4 memperlihatkan rugi-rugi daya dari setiap skenario yang di compare dengan daya losses saat normal. Hasil menunjukkan penurunan rugi-rugi daya pada setiap skenario setelah pemasangan PV. Tallo Lama menghasilkan nilai rugi yang terkecil dibanding unit lainnya. yakni 0,07727 p.u untuk daya aktif dan -0,40726 untuk daya reaktif. Sementara Panakukang menyumbang nilai rugi-rugi daya sebesar yakni 0.07301 p.u untuk daya aktif dan -0,40196 untuk daya reaktif, sedangkan Daya memiliki rugi-rugi daya terbesar diantara yang lainnya yakni sebesar 
$-0,06193$ p.u untuk daya aktif dan $-0,36342$ p.u daya reaktif.

Tabel 4. Rugi-rugi daya setelah dibandingkan sebelum pemasangan $\mathrm{PV}$

\begin{tabular}{ccc}
\hline PV Location & $\begin{array}{c}\text { REAL } \\
\text { POWER [p.u.] }\end{array}$ & $\begin{array}{c}\text { REACTIVE } \\
\text { POWER [p.u.] }\end{array}$ \\
\hline Tallo Lama & -0.07727 & -0.40726 \\
Panakukang & -0.07301 & -0.40196 \\
Daya & -0.06193 & -0.36342 \\
\hline
\end{tabular}

\section{Kesimpulan}

Penempatan PV yang tepat pada sistem interkoneksi di Sulbagsel dapat mengurangi rugirugi daya yang terjadi dan meningkatkan kestabilan sistem. Makalah ini mengusulkan sebuah algoritma baru untuk penempatan PV dengan menggunakan data solarGis. Dari solarGis, diperoleh daerah makassar memiliki irradiance bagus, dimana makassar di wakili 3 substantions.

Hasil penelitian ini memperlihatkan substations yang berada dikota Makassar (Tallo Lama, Panakukang, dan Daya) memiliki irradiance dan PV sensitivitas yang tinggi, dan berdasarkan hasil ini menjadi tempat yang direkomendasikan untuk penempatan PV karena dapat meningkatkan profil tegangan dan mengurangi rugi-rugi secara signifikan.

\section{Ucapan Terima Kasih}

Penulis menyampaikan rasa terima kasih dan penghargaan yang setinggi-tingginya kepada Ibu Ardiaty Arief, dan Bapak Muhammad Bachtiar Nappu, selaku pembimbing. Terimakasih juga yang sebesar-besarnya kepada Bapak dan Ibu Dosen yang telah memberikan banyak masukan dan bimbingannya, dan terimakasih juga kepada suami atas doa dan dukungannya, dan juga terimakasih buat semua teman-teman yang selalu membantu selama penulis melakukan penelitian.

\section{Referensi}

[1] A. Arief, Z. Dong, M. B. Nappu, and M. Gallagher, "Under voltage load shedding in power systems with wind turbine-driven doubly fed induction generators," Electr. Power Syst. Res., vol. 96, pp. 91-100, 2013.

[2] S. Microgrid, "Analisis dan Evaluasi Kestabilan Tegangan dengan Metode Continuation Power Flow," 2016, vol. 5, no. 2, pp. 528-533.

[3] U. Sultana, A. B. Khairuddin, M. M. Aman, A. S.
Mokhtar, and N. Zareen, "A review of optimum DG placement based on minimization of power losses and voltage stability enhancement of distribution system," Renew. Sustain. Energy Rev., vol. 63, no. September, pp. 363-378, 2016.

[4] M. Bachtiar and A. Arief, "Network Losses-Based Economic Redispatch for Optimal Energy Pricing in a Congested Power System," Energy Procedia, vol. 100, no. September, pp. 311-314, 2016.

[5] A. W. H. Sie, I. Z. Abidin, and H. Hashim, "A methodology to determine suitable placement of solar photovoltaic sources in the transmission system taking into account Voltage Stability Index (VSI)," in Conference Proceeding - 2014 IEEE International Conference on Power and Energy, PECon 2014, 2014, pp. 226-230.

[6] S. Kabir, O. Krause, and A. Haider, "Design of an optimal placement algorithm for large scale photovoltaic in sub-transmission networks," 3rd Int. Conf. Dev. Renew. Energy Technol., pp. 1-6, 2014.

[7] G. Guerra and J. A. Martinez, "A Monte Carlo method for optimum placement of photovoltaic generation using a multicore computing environment," IEEE Power Energy Soc. Gen. Meet., vol. 2014-Octob, no. October, pp. 1-5, 2014.

[8] S. Essallah, A. Bouallegue, and A. Khedher, "Optimal placement of PV-distributed generation units in radial distribution system based on sensitivity approaches," 2015 16th Int. Conf. Sci. Tech. Autom. Control Comput. Eng., pp. 513-520, 2015.

[9] P. Dinakara Prasad Reddy, V. C. Veera Reddy, and T. Gowri Manohar, "Optimal renewable resources placement in distribution networks by combined power loss index and whale optimization algorithms," J. Electr. Syst. Inf. Technol., pp. 1-17, 2017.

[10] A. Arief and M. B. Nappu, "DG placement and size with continuation power flow method," in Proceedings - 5th International Conference on Electrical Engineering and Informatics: Bridging the Knowledge between Academic, Industry, and Community, ICEEI 2015, 2015, pp. 579-584.

[11] I. Ben Hamida, "Optimal Integration of Solar Distributed Generations in Distribution Network Using SPEA2," pp. 368-373, 2016.

[12] Suresh Kumar Sudabattula, "ScienceDirect Optimal allocation of solar based distributed generators in distribution system using Bat algorithm," Perspect. Sci., vol. 8, pp. 270-272, 2016.

[13] S. Liu, F. Liu, T. Ding, and Z. Bie, "Optimal Allocation of Reactive Power Compensators and Energy Storages in Microgrids Considering Uncertainty of Photovoltaics," Energy Procedia, vol. 103, no. April, pp. 165-170, 2016.

[14] S. A. S. Mustaffa, I. Musirin, M. M. Othman, and N. H. Rosli, "Multi DGPV installation in transmission system for loss minimization," 2017 4th Int. Conf. Ind. Eng. Appl. ICIEA 2017, pp. 350-354, 2017.

[15] H. Outhred and M. Retnanestri, "Insights from the Experience with Solar Photovoltaic Systems in 
Australia and Indonesia," in Energy Procedia, 2015, vol. 65 , pp. 121-130.

[16] T. M. Razykov, C. S. Ferekides, D. Morel, E. Stefanakos, H. S. Ullal, and H. M. Upadhyaya, "Solar photovoltaic electricity: Current status and future prospects," Sol. Energy, vol. 85, no. 8, pp. 1580-1608, 2011.

[17] L. Serrano-Luján, N. Espinosa, J. Abad, and A. Urbina, "The greenest decision on photovoltaic system allocation," Renew. Energy, vol. 101, pp. 1348-1356, 2017.

[18] M. R. Rashel, A. Albino, T. Goncalves, and M. Tlemcani, "Sensitivity analysis of parameters of a photovoltaic cell under different conditions," Ski. 2016 - 2016 10th Int. Conf. Software, Knowledge, Inf. Manag. Appl., 2017.

[19] S. Daud, A. Fazliana, A. Kadir, C. K. Gan, and A. R. Abdullah, "Optimal allocation and sizing of Photovoltaic-based distributed generation for voltage dip improvement," pp. 89-94, 2016.

[20] Mochammad and Y. Elfita, "Pengaruh Suhu
Permukaan Photovoltaic Module 50 Watt Peak Terhadap Daya Keluaran yang Dihasilkan Menggunakan Reflektor dengan Variasi Sudut 0, 50, 60, 70, 80," Rotasi, vol. 12, no. 4, pp. 14-18, 2010.

[21] S. D. E. Nasional, Issn 2527-3000 issn 2527-3000. 2016.

[22] Solargis, "Global Horizontal Irradiation," accessed, 2017.

[23] L. Hakim, E. Komalasari, and H. Gusmedi, "Studi kemampuan pembebanan maksimum sistem interkoneksi sumbagsel."

[24] V. Ajjarapu and C. Christy, "The continuation power flow: A tool for steady state voltage stability analysis," IEEE Trans. Power Syst., vol. 7, no. 1, pp. 416-423, 1992.

[25] H. Hedayati, S. A. Nabaviniaki, and A. Akbarimajd, "A new method for placement of DG units in distribution networks," 2006 IEEE PES Power Syst. Conf. Expo. PSCE 2006 - Proc., vol. 23, no. 3, pp. 1904-1909, 2006. 